dled devices from other hospital areas, resulting in continued needlestick injuries. Many of the new devices are expensive, and it is not clear that they will be cost-effective in all areas of the hospital. Careful evaluation and implementation of safety devices for specific intermediate-risk and high-risk functions (eg, safe phlebotomy devices, safe intravenous catheter devices) should be a more cost-effective approach.

Devices adopted for use must have the best overall efficacy, costeffectiveness, safety, and customer satisfaction profile. Ideally, a failure of any of these conditions should result in rejection of the device.

Paul B. L'Ecuyer, MD

Victoria J. Fraser, MD

Washington University School of Medicine St Louis, Missouri

\title{
NIOSH Publishes Latex Allergy Alert
}

\section{Gina Pugliese, RN, MS} Martin S. Favero, PhD

The National Institute for Occupational Safety and Health (NIOSH) recently published an "Alert on Preventing Allergic Reactions to Natural Rubber Latex in the Workplace." This alert was developed in response to the increase in recent years of reports of allergic reactions to natural rubber latex among workers who use gloves and other products containing latex. Latex gloves have proved effective in preventing transmission of many infectious diseases to healthcare workers; however, for some workers, exposures to latex may result in skin rashes; hives; flushing; itching; nasal, eye, or sinus symptoms; asthma; and (rarely) shock.

At present, scientific data are incomplete regarding the natural history of latex allergy. Also, improvements are needed in methods used to measure proteins causing latex allergy. This alert presents the existing data and describes six case reports of workers who developed latex allergy. The document also presents NIOSH recommendations for minimizing latex-related health problems in workers while protecting them from infectious materials. These recommendations include reducing exposures, using appropriate work prac- tices, training and educating workers, monitoring symptoms, and substituting nonlatex products when appropriate.

NIOSH requests that employers, owners, editors of trade journals, safety and health officials, and labor unions bring the recommendations in this alert to the attention of all workers who may be exposed to latex. Copies of this document (NIOSH Alert: Preventing Allergic Reactions to Natural Rubber Latex in the Workplace: DHHS [NIOSH] Pub No. 97-135) may be obtained from NIOSH, 4676 Columbia Pkwy, Cincinnati, OH 45226-1998; fax, 513-533-8573; telephone, 800-356-4674.

\section{Correction}

\section{High Frequency of Pseudobacteremia at a University Hospital}

A reference was cited incorrectly in the Concise Communication "High Frequency of Pseudobacteremia at a University Hospital” (1997;18:200-202). Reference 10 should have cited Ann Intern Med, not Arch Intern Med, as the source: Bates DW, Cook EF, Goldman L, Lee TH. Predicting bacteremia in hospitalized patients. Ann Intern Med 1990; 113:495-500. We apologize for any inconvenience the error may have caused. 